\title{
Constructing Indicators for Measuring Provincial Sustainable Development Index in Vietnam
}

\author{
Van Canh Truong ${ }^{1}$, Andrzej Lisowski ${ }^{1, *}$ \\ ${ }^{1}$ University of Warsaw, Faculty of Geography and Regional Studies, Krakowskie Przedmieście Av. 30 \\ 00-927 Warsaw, Poland
}

\begin{abstract}
Sustainable development is zeitgeist of our age. It is one kind of development that in this trajectory humanity can create a stable and developed socio-economic foundations, conserve environment and therefore able to continue for a long time. Using indicators is one of the best ways to monitor and measure the progress toward sustainable development. In this paper we have proposed the way to create indicators for measuring provincial sustainable development index in Vietnam. We firstly made a framework of elements for economic, social and environmental component and compiled a list of indicators of 20 national and international agencies in the world. We then applied the SMART framework (Specific, Measurable, Achievable, Relevant, and Time-related) to choose indicators which will be relevant for Vietnam and put them back to the elements. We then have 39 relevant indicators with 12 indicators for economy, 17 indicators for social and 10 indicators for environmental component. Finally, we have established the way to determine the worst and best value for each indicator from available data for countries in the world. Key words - indicators; Vietnam; sustainable development; index.
\end{abstract}

\section{The conceptualization of sustainable development}

In the report of the United Nations Commission on Environment and Development, known widely by the name "Our Common Future" in the Brundtland Commission in 1987, a classic definition of the concept of sustainable development, one that was used for the next twentyfive years, was first introduced: sustainable development is development that meets the needs of the present without compromising the ability of future generations to meet their own needs. [1]

Over the years the concept of sustainable development (SD) has led to various definitions, understandings, instrumentations, evolved into a more practical approach, focusing less on intergenerational needs and more on the holistic approach linking economic development, social inclusion, and environmental sustainability, meaning that each of these dimensions is as important as the next one. [5]

SD became political objective of United Nations with several important summits. Some of key SD policy frameworks include comprehensive action plan Agenda 21, UN's Global Initiative "Millennium Development Goals (2001). The holistic approach of sustainable development was emphasized in "Report of World Summit on Sustainable Development"

* Corresponding author: trvcanh1712@gmail.com 
in 2002 at the UN World Summit on Sustainable Development in Johannesburg, and again in "The Future We Want" at Rio+20 Summit in 2012. A plan of action for people, planet and prosperity showed in the report "Transforming Our World: The 2030 Agenda for Sustainable Development" after 2030 Agenda for Sustainable Development. [13]

\section{Sustainable development in the case of Vietnam}

Vietnam, officially the Socialist Republic of Vietnam, is the easternmost country on the Indochina Peninsula in Southeast Asia. With an estimated 91.7 million inhabitants as of 2015, it is the world's 14th-most-populous country, and the ninth-most-populous Asian country. It covers a total area of approximately $330,966 \mathrm{~km} 2$. Vietnam is divided into 58 provinces. There are also five municipalities, which are administratively on the same level as provinces. [4]

For sustainable development objectives to be realized in Vietnam, a series of policies have been adopted in the economic, social and environmental fields and with the implementation of international commitments on sustainable development to which Vietnam is a signatory. Vietnam has recorded remarkable achievements in economic, social and environmental sectors, all three pillars of sustainable development.

In the economic field, Vietnam has been recognized as one among the developing countries which have made notable achievements in economic reform toward growth and poverty reduction. Vietnam has jumped out of the group of poor countries into the group of middle-income countries. [9]

In the social field, initial encouraging achievements have been recorded in hunger eradication, poverty reduction, population, job creation, education and health care. Social security has been attended to so as to ensure stability for the people's livelihoods and productivity, especially given the high inflation and frequent natural disasters. Vietnam's gender equality index is higher than countries with a similar level of development and income. The HDI has also improved over the years. [9]

In the environmental field, the system of policies and laws on environmental protection has been in place in a sufficient and comprehensive manner. Many of the tasks regarding pollution prevention and control and biodiversity conservation have brought about heartening results. Integration of environment-related issues into strategies, schemes and plans right at the designing stage as well as into projects at the stage of investment preparation has helped limit and minimize environmental pollution. [9]

On the way to continued implementation of its national sustainable development objectives, Vietnam is faced with many inherent or emerging challenges, including: Climate change has made its presence increasingly visible, with an increase in natural disasters, causing huge human and material destruction to the Central coastal region and significant destruction to many others. Natural resources, especially water and biodiversity, have been seriously degenerated. In certain localities, land and minerals resources have suffered from exhaustive or highly wasteful exploitation. Environmental pollution, the prolonged degeneration of the environment as a consequence of the war (bombs, landmines, Agent Orange/dioxin) and the environmental pollution due to the present socio-economic development, constitute a very grave challenge to Vietnam in the sustainable development process. [9]

\section{Indicator selection method}

Indicators are simple measures related to something more complex of primary interest. To ensure that selected indicators are applicable, they must fit with themes of sustainable development considering that some of them are already mentioned in policy documents. The selection of indicators followed by the method which is presented below: 
+ First step: Make a framework of elements. The research endorsed three dimensions of sustainable development: social wellbeing, economic opportunity, and environmental quality and agreed upon the elements necessary to ensure each [7]. The result is the elements necessary for sustainable development:

Table 1. The elements for three components of sustainable development

\begin{tabular}{|l|l|}
\hline \multicolumn{1}{|c|}{ Components } & \multicolumn{1}{c|}{ Elements } \\
\hline \multirow{5}{*}{ Economic } & Prosperity \\
\cline { 2 - 2 } & Employment \\
\cline { 2 - 2 } Social & Investment \\
\cline { 2 - 2 } & Competitiveness \\
\hline & Education \\
\cline { 2 - 2 } & Living conditions \\
\cline { 2 - 2 } & Poverty \\
\hline \multirow{5}{*}{ Environmental } & Inequality \\
\cline { 2 - 2 } & Heath \\
\cline { 2 - 2 } & Safety \\
\hline & Resources \\
\cline { 2 - 2 } & Water and sanitation \\
\cline { 2 - 2 } & Air quality \\
\cline { 2 - 2 } & Waste / Reuse / Recycle \\
\hline
\end{tabular}

Source: Authors' analysis

+ Second step: Compile a list of indicators used for evaluating sustainable development in countries, institutes, organizations in the world. In this study, researcher explore how a standard set of sustainable development indicators could be drawn or adapted from existing systems, the first steps towards creating the standardized system needed to understand national sustainable development status and trends. [7]

Following an exploration of the literature on indicators and indicator systems, the research began a broad analysis of the 20 identified indicator systems. While the list of 20 systems are not comprehensive, can be considered representative of the types of organizations that are active in the area. The 20 systems, shown below, fall into three broad categories, Institutional, NGO, and Governmental from 1998 to 2016.

Table 2. The 20 identified indicator systems

\begin{tabular}{|c|l|c|c|c|c|c|}
\hline No. & \multicolumn{1}{|c|}{ Countries/Regions } & Year & Economic & Social & Environmental & Total \\
\hline 1 & USA & 1998 & 13 & 11 & 16 & 40 \\
\hline 2 & UNEP- MAP* & 1999 & 40 & 23 & 67 & 130 \\
\hline 3 & Finland & 2000 & 23 & 28 & 31 & 82 \\
\hline 4 & Korean & 2006 & 14 & 24 & 26 & 64 \\
\hline 5 & Asian Development Bank & 2006 & 24 & 30 & 8 & 62 \\
\hline 6 & United Nations & 2007 & 29 & 31 & 36 & 96 \\
\hline 7 & The MDGIs** & 2008 & 19 & 31 & 10 & 60 \\
\hline 8 & Germany & 2010 & 8 & 12 & 8 & 28 \\
\hline 9 & France & 2010 & 16 & 21 & 17 & 54 \\
\hline 10 & Poland & 2011 & 23 & 31 & 22 & 76 \\
\hline 11 & Israel & 2011 & 7 & 7 & 12 & 26 \\
\hline
\end{tabular}




\begin{tabular}{|c|l|c|c|c|c|c|}
\hline 12 & Vietnam & 2013 & 9 & 13 & 19 & 41 \\
\hline 13 & Australia & 2013 & 16 & 26 & 14 & 56 \\
\hline 14 & Malaysia & 2013 & 8 & 24 & 8 & 40 \\
\hline 15 & Taiwan & 2013 & 24 & 30 & 44 & 98 \\
\hline 16 & Nordic Region & 2013 & 4 & 7 & 12 & 23 \\
\hline 17 & United Kingdom & 2013 & 8 & 11 & 16 & 35 \\
\hline 18 & OECD & 2014 & 20 & 6 & 23 & 49 \\
\hline 19 & EU commission & 2015 & 49 & 38 & 22 & 109 \\
\hline 20 & SDSN*** & 2016 & 17 & 39 & 23 & 79 \\
\hline & & & 371 & 443 & 434 & 1248 \\
\hline
\end{tabular}

* United Nations Environment Program- Mediterranean Action Plan

** The Millennium Development Goals Indicators

*** Sustainable Development Solutions Network

Source: Authors' analysis and calculations

+ Third step: Apply the SMART framework to take relevant indicators. The acronym SMART, put forth by the European Union and Statistical Institute for Asia and Pacific (2007) describes the qualities of a 'good' indicator. Identified during the literature review, the qualities (Specific, Measurable, Achievable, Relevant, and Time-related) were endorsed by the SUD Working Group at its August 2010 meeting. [7] In this paper, about S for specific in the SMART, the researcher also concern about the $\mathrm{S}$ for spatial.

The indicators in this study were chosen on the basis that they were, as far as possible, quantifiable and spatially specific. It was also important to check if indicators were capable of capturing change over time and territory, and thus provide information sensitive to change in a timely manner. Based on these concerns and the SMART framework, indicators were filtered based on assessment of each of the following questions:

- Does the indicator address the policy objectives and development priorities (i.e. overall priority themes) of the case studies?

- Are the indicators available and does the indicator enable assessment of the performance and dynamics of balanced territorial development (i.e. can it be mapped to illustrate spatial patterns)?

- Is the indicator regularly measured (i.e. are there reliable and regularly updated datasets available or monitoring arrangements in place)?

- Does the indicator effectively provide information sensitive to change to timely aid decision-making processes?

- Is the indicator well understood by planners and decision-makers (i.e. can it communicate the results in a concise and accessible manner)? [14]

So a number of indicators were measurable, but not achievable, meaning they asked for information that could be collected, but to do so would be prohibitively expensive or difficult. In the economic and social dimensions, in particular, many indicators were removed for referencing resource- intensive one-time surveys. Some indicators were also irrelevant, given the goals of the project. Interpreting the time-related criterion proved more of a challenge, but researchers liken it to timely, that is whether an indicator is based upon current, continuous data that can be tracked over time, as opposed to old surveys or databases. [7] If most criteria were met, the indicator was selected, if not - the indicator was discarded. If the indicator partially met criteria it was put on a list of additional indicators.

+ Fourth step: Put the relevant indicator after applying SMART framework to each of elements.

+ Fifth step: Determining the worst and best value for each indicator. We order data for each indicator from worst or min (0) to best or max (1 or 100). In some cases the highest numerical value on an indicator is "worst" (e.g. infant mortality rate) while for other indicators 
the highest numerical value is "best" (e.g. life expectancy). We are going to create the worst and the best value for each indicator. In most cases the best and worst score is the natural "perfect" and technically feasible target in line with the principle of "leaving no one behind" (e.g. zero extreme poverty, zero undernourishment, 100\% school completion). [10] In some cases no such "perfect" target exists as the theoretical optimum may not be achievable or might be undefined (e.g. child mortality rate, physician density, traffic deaths, life expectancy...). We can take thresholds for indicators from data for the sample countries in the world. To determine the worst value for each indicator, we first remove the worst $2.5 \%$ of observations (mean the sample countries in the world) in order to ensure that our scoring is not overly influenced by outliers. We then identify the next-worst value on each indicator and apply this value to the bottom 2.5 percentile of the distribution. To identify the best value we can use average of the top 5 values in the sample of countries for that indicator. All countries that exceed the average of the best values are assigned the best value. [10]

\section{Results and discussion}

After applying the method to select indicators, researcher have constructed a list of 39 indicators with 12 indicators for economic component, 17 indicators for social component and 10 indicators for environmental component. All of them are met the criteria for selecting indicators and have been set up the best and the worst values as the threshold for the next step of measurement. The result of selected indicators is shown in Table 3.

Table 3. The core indicators for measuring provincial sustainable development in Vietnam

\begin{tabular}{|c|c|c|c|c|c|c|}
\hline Component & Element & Indicator & $\mathbf{N}$ & $\begin{array}{l}\text { Best } \\
(=1)\end{array}$ & $\begin{array}{l}\text { Worst } \\
(=0)\end{array}$ & Source \\
\hline \multirow{12}{*}{ Economic } & \multirow{5}{*}{ Prosperity } & GDP per capita (PPP USD) & 177 & 96000 & 1184 & WB, 2015 \\
\hline & & $\begin{array}{l}\text { Annual growth rate of labor } \\
\text { productivity }(\%)\end{array}$ & 183 & 10.8 & -22.3 & WB, 2015 \\
\hline & & $\begin{array}{l}\text { Percentage of budget revenue and } \\
\text { expenditure accounts per GDP }(\%)\end{array}$ & 107 & 25.7 & -5.1 & WB, 2015 \\
\hline & & Urban population rate $(\%)$ & 195 & 100 & 16.3 & WB, 2015 \\
\hline & & $\begin{array}{l}\text { Proportion of GDP generated by } \\
\text { service }(\%)\end{array}$ & 151 & 83.7 & 37.5 & WB, 2015 \\
\hline & \multirow[b]{3}{*}{ Employment } & Unemployment rate at ages $15+(\%)$ & 181 & 0.5 & 25.8 & ILO, 2015 \\
\hline & & Employment to population ratio (\%) & 169 & 85 & 37.2 & WB, 2015 \\
\hline & & $\begin{array}{l}\text { Percentage of advanced trained } \\
\text { employed workers at } 15 \text { years of age } \\
\text { and above }(\%)\end{array}$ & 71 & 57.4 & 8.0 & $\begin{array}{c}\text { ILO, } \\
2014-2015\end{array}$ \\
\hline & \multirow{3}{*}{ Investment } & $\begin{array}{l}\text { Expenditure on Research and } \\
\text { Development as a percent of GDP (\%) }\end{array}$ & 67 & 3.7 & 0 & $\begin{array}{l}\text { UNESCO, } \\
2015 \\
\end{array}$ \\
\hline & & $\begin{array}{l}\text { Expenditure on education as a percent } \\
\text { of GDP }(\%)\end{array}$ & 112 & 8.2 & 1.6 & $\begin{array}{l}\text { UNESCO, } \\
2015\end{array}$ \\
\hline & & $\begin{array}{l}\text { Expenditure on health services as a } \\
\text { percent of GDP }(\%)\end{array}$ & 188 & 14.2 & 2.6 & WB, 2014 \\
\hline & Competitiveness & Provincial Competitiveness Index & & 1 & 0 & Optimum \\
\hline
\end{tabular}

\begin{tabular}{|l|l|l|c|c|c|c|}
\hline Component & \multicolumn{1}{|c|}{ Element } & \multicolumn{1}{|c|}{ Indicator } & N & $\begin{array}{c}\text { Best } \\
(=1)\end{array}$ & $\begin{array}{c}\text { Worst } \\
(=\mathbf{0})\end{array}$ & Source \\
\hline \multirow{3}{*}{ Social } & Education & $\begin{array}{l}\text { Adult literacy rate (\%) } \\
\text { Population aged 5 and over ever or } \\
\text { never attending school (\%) }\end{array}$ & 98 & 0 & 45.0 & $\begin{array}{c}\text { UNESCO, } \\
2014\end{array}$ \\
\hline & Combined gross enrolment ratio (\%) & & 100 & 0 & 0 & Optimum \\
\hline
\end{tabular}




\begin{tabular}{|c|c|c|c|c|c|}
\hline \multirow{3}{*}{$\begin{array}{l}\text { Living } \\
\text { condition }\end{array}$} & $\begin{array}{l}\text { Proportion of household own } \\
\text { permanent house }\end{array}$ & & 100 & 0 & Optimum \\
\hline & $\begin{array}{l}\text { Percentage of households using } \\
\text { electricity }(\%)\end{array}$ & & 100 & 0 & Optimum \\
\hline & $\begin{array}{l}\text { Proportion of households with } \\
\text { broadband internet access (\%) }\end{array}$ & & 100 & 0 & Optimum \\
\hline \multirow{2}{*}{ Poverty } & $\begin{array}{l}\text { Poverty rate }(\%) \text { - national poverty } \\
\text { line }\end{array}$ & 117 & 0 & 64.6 & $\begin{array}{c}\text { WB, } \\
2009-2015\end{array}$ \\
\hline & Cereals per yield (ton/ha) & 171 & 8.6 & 0.5 & $\begin{array}{l}\text { WB, FAO, } \\
2014\end{array}$ \\
\hline \multirow{3}{*}{ Inequality } & Gini index & 138 & 0.26 & 0.61 & WB, 2013 \\
\hline & $\begin{array}{l}\text { Female labor force participation rate } \\
(\% \text { male })\end{array}$ & 121 & 100 & 22.5 & $\begin{array}{c}\text { SDSN, } \\
2010-2014\end{array}$ \\
\hline & Sex ratio at birth (male/100 female) & 194 & 105 & 110 & CIA, 2016 \\
\hline \multirow{4}{*}{ Health } & $\begin{array}{l}\text { Full immunization coverage among } \\
\text { children under } 1 \text { year of age }(\%)\end{array}$ & & 100 & 0 & Optimum \\
\hline & $\begin{array}{l}\text { Proportion of malnutrition of children } \\
\text { under } 5 \text { (underweight) - } \%\end{array}$ & 129 & 0 & 33.0 & $\begin{array}{l}2005-2015 \\
\text { UNICEF, } \\
\text { WHO \& } \\
\text { WB }(2015)\end{array}$ \\
\hline & $\begin{array}{l}\text { Under } 5 \text { mortality rate (per } 1.000 \text { live } \\
\text { births) }\end{array}$ & 189 & 2.3 & 114.7 & WB, 2015 \\
\hline & Average life expectancy at birth & 188 & 83.0 & 52.0 & WB, 2014 \\
\hline \multirow[t]{2}{*}{ Safety } & $\begin{array}{l}\text { Total persons convicted per } 100.000 \\
\text { population }\end{array}$ & 80 & 0 & 2775 & $\begin{array}{c}2010-2014 \\
\text { UNODC, } \\
2014\end{array}$ \\
\hline & $\begin{array}{l}\text { Proportion of death due to traffic } \\
\text { accident per } 100.000 \text { population }\end{array}$ & 179 & 0 & 33.2 & $\begin{array}{l}\text { WHO, } \\
2013\end{array}$ \\
\hline
\end{tabular}

\begin{tabular}{|c|c|c|c|c|c|c|}
\hline Component & Element & Indicator & $\mathbf{N}$ & $\begin{array}{l}\text { Best } \\
(=1)\end{array}$ & $\begin{array}{l}\text { Worst } \\
(=0)\end{array}$ & Source \\
\hline \multirow{10}{*}{$\begin{array}{l}\text { Environ- } \\
\text { mental }\end{array}$} & \multirow{3}{*}{ Resources } & $\begin{array}{l}\text { Change rate of forest areas } 2005- \\
2015(\%)\end{array}$ & 192 & 36.5 & -22.6 & WB, 2015 \\
\hline & & $\begin{array}{l}\text { Percentage of natural forest area }(\% \\
\text { of total forest area) }\end{array}$ & & 100 & 0 & Optimum \\
\hline & & $\begin{array}{l}\text { Change in agriculture land 2004- } \\
2014(\%)\end{array}$ & 191 & 0.2 & -0.4 & WB, 2013 \\
\hline & \multirow{2}{*}{$\begin{array}{l}\text { Water } \\
\text { and } \\
\text { sanitation }\end{array}$} & $\begin{array}{l}\text { Proportion of household with access } \\
\text { to improved sanitation }(\%)\end{array}$ & 179 & 100 & 12.1 & WB, 2015 \\
\hline & & $\begin{array}{l}\text { Percentage of household access } \\
\text { potable water }(\%)\end{array}$ & 183 & 100 & 51.5 & WB, 2015 \\
\hline & \multirow{3}{*}{ Air quality } & $\begin{array}{l}\text { Proportion of households using solid } \\
\text { fuels for cooking }(\%) \text { - coal or } \\
\text { biomass (such as dung, charcoal, } \\
\text { wood, or crop residues) }\end{array}$ & & 0 & 100 & Optimum \\
\hline & & $\begin{array}{l}\text { Percentage of households using } \\
\text { motorbike }(\%)\end{array}$ & 44 & 86 & 6.4 & $\begin{array}{l}\text { Pew } \\
\text { Research } \\
\text { Center }\end{array}$ \\
\hline & & $\begin{array}{l}\text { Annual mean concentration of PM2.5 } \\
\left(\mu \mathrm{g} / \mathrm{m}^{3}\right)\end{array}$ & 191 & 4.0 & 71.0 & WB, 2015 \\
\hline & \multirow{2}{*}{$\begin{array}{l}\text { Waste / } \\
\text { Reuse / } \\
\text { Recycle }\end{array}$} & $\begin{array}{l}\text { The total amount of solid waste } \\
\text { collected per capita (kg/person/day) }\end{array}$ & $63^{*}$ & 0.1 & 0.8 & GSO, 2015 \\
\hline & & $\begin{array}{l}\text { Proportion of solid waste that are } \\
\text { treated according to national } \\
\text { standards }(\%)\end{array}$ & & 100 & 0 & Optimum \\
\hline
\end{tabular}

Source: Authors' analysis and calculations 


\subsection{Economic component}

Overall $17 \mathrm{key}$ indicators related to economic dimension of sustainable development for Vietnam were selected. Among those are 5 indicators for assessment of prosperity of economic. The key indicators for employment are three and also three key ones for investment. Especially, we recommended using a special indicator to assess the business environment in Vietnam which is Provincial Competitiveness Index (PCI).

Several related tourism indicators were not included among key economic indicators. Economic dimension also did not included infrastructure and transportation related indicators. We know that this is so important to use those indicators for measuring sustainable development but the data for those ones is not spatial available by provinces.

\subsection{Social component}

Social dimension included 17 indicators. Not the same situation in economic and environmental dimension, the indicators for social dimension are quiet overwhelming. Among 17 indicators 3 education indicators, the role of education is clearly seen as priority among stakeholders. Two of the education indicators which are used so popular to overall see the knowledge of population are adult literacy rate and combined gross enrolment ratio. Several indicators are suggested to capture living condition. In the social dimension the research concentrated on the indicators for health gathering to children. Sex ration at birth indicator was included in the list of key indicators for social dimension. This is essential indicator in the context of Vietnam due to the preferring for male children.

Citizen satisfaction with life in Vietnam is not measured but is preferred. Growing importance of life quality and wellbeing means that this dimension will have to be addressed.

\subsection{Environmental component}

The data for environment is so limited, especially provincial data. Environmental dimension contains 10 indicators most of which are already used. Based on available indicators, environmental dimension emphasizes availability of resources, water and sanitation, air quality and reuse or recycle of waste. Among preferred an indicators that is included, but not yet used is annual mean concentration of PM2.5 $\left(\mu \mathrm{g} / \mathrm{m}^{3}\right)$, but data for this indicator we will have from the satellite images. To evaluate air quality the researcher has concerned about two aspects: outdoor and indoor air quality. We have decided to take indicator like proportion of households using solid fuels for cooking (\%) for indoor air quality and percentage of households using motorbike for outdoor air quality.

Waste management can also have profound impact on environment, indicators of waste management were selected as key indicators. These were - The total amount of solid waste collected per capita ( $\mathrm{kg} /$ person/day) and Proportion of solid waste that are treated according to national standards $(\%)$.

\section{Conclusion}

Indicators reflect certain development priorities, but only some indicators are able to communicate complex relationships between phenomena in a simple way and in a manner, which is easily understood. Selecting indicators is not a straightforward task [14]. To measure the status of sustainable development of a country according to the spatial change, we must also base on the recent statistical data which we can have to use. The study has explored a list of indicators of 20 national and international agencies in the world. We then applied the SMART framework (Specific, Measurable, Achievable, Relevant, and Time- 
related) to choose indicators which will be relevant for Vietnam. We then have 39 relevant indicators with 12 indicators for economic, 17 indicators for social and 10 indicators for environmental component. Finally, we have established the way to determine the worst and best value for each indicator from available data for countries in the world. Although the study constructs the list of limited indicators, it finds the core indicators in all sustainable development dimensions which we can use the recent statistical data to measure. But a lot of essential indicators about transportation, economic, wellbeing, environmental quality and so forth are still missing in the list of core indicators due to the missing the data.

\section{References}

1. Brundtland Commission, UN, Our Common Future (1987)

2. D. Reid, Sustainable Development: An Introductory Guide, Earthscan in UK and US, (2013)

3. ESPON, KITCASP, Key Indicators of Territorial Cohesion and Spatial Planning, Target Analysis, Final Report, Scientific Report (2013), URL:

http://www,espon,eu/main/Menu_Projects/Menu_TargetedAnalyses/kitcasp,html,

4. General Statistic Office of Vietnam, Statistical Yearbook of Vietnam (2016)

5. D. Jeffrey, Sachs, The Age of Sustainable Development, Columbia University Press (2015)

6. Jennifer A, Elliott, An introduction to sustainable development (third edition), Published by Routledge Taylor \& Francis (2006)

7. Penn Institute for Urban Research, Sustainable Urban Development Indicators for the United States (2011)

8. S. Bell and S. Morse, Sustainability Indicators: Measuring The Immeasurable (second edition), Earthscan (2008)

9. Socialist Republic of Vietnam, Implementation of Sustainable Development in Vietnam National Report in Rio+20 (2012)

10. Sustainable Development Solutions Network (SDSN), SDG Index and Dashboards Global Report, New York: Bertelsmann Stiftung and Sustainable Development Solutions Network (2016)

11. Sustainable Development Solutions Network, An Action Agenda for Sustainable Development (2013)

12. Tatyana P, Soubbotina, Beyond Economic Growth: An Introduction for Sustainable Development, The International Bank for Reconstruction and Development, WB (2004)

13. UN, Transforming our world: The 2030 Agenda for Sustainable Development (2015)

14. V. Visvaldisa, G. Ainhoab, P. Ralfsc, Selecting indicators for sustainable development of small towns: The case of Valmiera municipality, URL:

http://www.sciencedirect.com/science/article/pii/S1877050913012763, Published by Elsevier (2013) 